\title{
地形因素对外来入侵种紫茎泽兰的影响
}

\author{
卢志军 马克平* \\ (中国科学院植物研究所植被数量生态学重点实验室, 北京 100093)
}

摘 要 在紫茎泽兰 (Eupatorium adenophorum) 的分布区内设置 171 块临时样地, 研究它的盖度和多度与经纬度、海 拔、坡向、坡度、风向坡等地形因素的关系。结果表明, 紫茎泽兰入侵最严重地区位于 $102^{\circ} \mathrm{E}$ 左右, 随着纬度增加入 侵能力逐渐下降, 但不显著 $(p>0.05)$, 紫茎泽兰在中国的分布以云贵高原, 尤其是云南高原为主体, 通过云贵高原 与原产地墨西哥、哥斯达黎加的气候条件对比，推断紫茎泽兰将来在中国的分布区主体还将局限在云贵高原，但不 排除在某些局域气候条件下, 形成斑块的可能, 该次调查的海拔范围为 $75 \mathrm{~m} \sim 2330 \mathrm{~m}$, 以 $200 \mathrm{~m}$ 为一个海拔梯度， 多项式回归分析显示 紫茎泽兰的盖度与多度随着海拔升高而增加 $(p<0.05)$, 但在 $2000 \mathrm{~m}$ 左右已趋平缓, 表明紫 茎泽兰适宜生长在海拔 $2000 \mathrm{~m}$ 左右; ANOVA 的结果显示 坡向对紫茎泽兰的入侵影响显著 $(p<0.05)$, 通过多重 比较发现 北坡和南坡的盖度比东坡大 $(p<0.05)$; 北坡的多度比东坡大 $(p<0.05)$, 说明东坡不易被紫茎泽兰入 侵, 而北坡和南坡紫茎泽兰的盖度和多度差异并不显著 $(p>0.05)$, 说明温度与湿度可能不是造成不同坡向紫茎泽 兰入侵差异的主导因素 坡度对紫茎泽兰入侵的影响并不显著 $(p>0.05)$; 风向坡对紫茎泽兰的盖度影响不显著 $(p$ $>0.05)$, 而对多度的影响显著 $(p<0.05)$, 背风坡的多度显著大于侧风坡。

关键词 紫茎泽兰 入侵种 地形因素

\section{THE INFLUENCE OF TOPOGRAPHICAL FACTORS ON THE INVASION OF THE ALIEN SPECIES , EUPATORIUM ADENOPHORUM}

\author{
LU Zhi-Jun and MA Ke-Ping * \\ (Laboratory of Quantitive Vegetation Ecology, Institute of Botany , Chinese Academy of Sciences , Beijing 100093 , China)
}

\begin{abstract}
To study the distribution of Eupatorium adenophorum in China and the relationship between its invasion and topographical factors , including elevation , aspect , slope and wind slope , 171 plots were established in 12 vegetation provinces within this species range. The results indicated that the invasion of $E$. adenophorum mostly occured in regions near $102^{\circ} \mathrm{E}$ and declined with latitude, but not significant $(p>0.05)$. The range of $E$. adenophorum in China was mainly on the Yungui Plateau , particularly the Yunnan Plateau. Based on climatic comparisons between the Yungui Plateau and this species native range in Mexico and Costa Rica , we concluded that the future range of $E$. adenophorum in China would be confined largely to the Yungui Plateau , although patches are likely to occur in other regions with suitable climatic conditions. The elevation range of this species was from $75 \mathrm{~m}$ to $2330 \mathrm{~m}$ in our investigation. Using polynomial regressions, we concluded that the abundance and coverage of $E$. adenophorum increased with elevation $(p<0.05)$, but at about $2000 \mathrm{~m}$ elevation, the line became horizontal , suggesting that $E$. adenophorum preferred elevations of about $2000 \mathrm{~m}$. An ANOVA analysis showed that the influence of aspect on the coverage of $E$. adenophorum was significant. Multiple comparison tests suggested that the coverage of $E$. adenophorum on north and south facing slopes was greater than that on east facing slopes , indicating a strong resistance of east facing slopes to the invasion of $E$. adenophorum. The difference between population coverage and abundance on north and south facing slopes was not significant $(p>0.05)$, indicating that temperature and moisture were not the dominant factors influencing the invasion of $E$. adenophorum on different aspects. The influence of slope on the invasion of $E$. adenophorum was not significant $(p>0.05)$. The results of the ANOVA analysis indicated that the influence of wind slope on the coverage of $E$. adenophorum was not significant $(p>0.05)$ but significantly affected the abundance of $E$. adenophorum $(p<0.05)$ with the abundance of $E$. adenophorum greater on the leeward than on the lateral side.
\end{abstract}

Key words Eupatorium adenophorum, Invasive species, Topographical factor 
紫茎泽兰 ( Eupatorium adenophorum) 原产中美洲 墨西哥、哥斯达黎加等地 (Auld，1969；1970;刘伦辉 等, 1985; 孟秀祥等,2003;Papes \& Peteron , 2003) 20 世纪 40 年代从中缅边境传入我国云南地区 (赵国晶 等,1989 ; 强胜,1998)。1953 年, 云南省与缅甸接壤 的沧源、耿马最早发现了紫茎泽兰 (吴仁润,1984)。 50 年后的今天, 紫茎泽兰不仅已经在云南全省肆 虐，而且扩散到广西、贵州、四川，甚至重庆、湖北，台 湾也有分布。该入侵种已经对我国西南地区，乃至 华中、华南地区的生物多样性构成了巨大的威胁, 并 给西南地区农林牧业生产带来了巨大的损失。2003 年，国家环境保护总局和中国科学院联合发布的入 侵肿名录中 紫茎泽兰名列首位 (国家环境保护总局 等 2003)。作为一种危害严重的世界性杂草(强胜， 1998 ），人们首先关注的是它的分布、危害和防除等 (刘伦辉等,1985; 赵国晶等,1989; 向业勋,1991; 王 洪畑等, 1994)。但对生态学方面关注较少, 研究相 对薄弱, 尤其是地形因素对这种恶性杂草的影响报 道很少。

在陆地环境中, 温度和水分都很重要而且密切 结合在一起对生物起作用，一般把它们看成气候因 素的最重要部分 (李博,1993)。而经纬度、海拔、坡 向、坡度等地形因素影响光照、温度、降水等因子的 分布，对生物产生间接作用（李博，1999），具有较明 显的生态指示意义( 沈泽昊等, 2000)。同时 地形因 素对土壤、繁殖体散布等也有影响。因此, 探讨地形 因素的影响是紫茎泽兰研究中的重要课题, 对于研 究分布、扩散以及防除具有重要的参考价值。本文 通过在紫茎泽兰分布区内建立临时样地调查入侵情 况, 探讨紫茎泽兰入侵与经纬度、海拔、坡向、坡度和 风向坡等因素之间的关系,丰富该物种生态学方面 研究,为预警和防除提供基础资料。

\section{1 研究方法}

根据文献资料 ${ }^{1)}$ (刘伦辉等, 1985; 赵国晶等, 1989 ;向业勋, 1991; 王洪畑等, 1994; 强胜, 1998; 李振 宇等,2002 孟秀祥等,2003)勾画出紫茎泽兰分布的 大致范围 (图 1)。

一个地区的植被是水热条件综合主导作用的结 果，对于该地区的降雨、温度等因子具有一定的指示 作用。根据《中国植被》(吴征镒，1995)的区划方案，
将紫茎泽兰的分布区划分为 12 个小区 (相当于植被 区等级，Province）。在每个小区内，根据优势种的生 活型 (灌草丛、灌丛、针叶林、落叶阔叶林和常绿阔叶 林) 分别选取有紫茎泽兰分布的典型地段设置样地 调查入侵情况。对于每一类型的植被, 按郁闭度大 小 $(0 \sim 30 \%, 31 \% \sim 70 \%$ 和 $71 \% \sim 100 \%) 3$ 个重复 (Parendes \& Jones 2000)。针叶林和阔叶林的样方大 小为 $20 \mathrm{~m} \times 20 \mathrm{~m}$, 在每个样方的对角线上设置 3 个 $5 \mathrm{~m} \times 5 \mathrm{~m}$ 的样方；灌丛样方大小 $5 \mathrm{~m} \times 5 \mathrm{~m}$;灌草丛 样方大小为 $1 \mathrm{~m} \times 1 \mathrm{~m} 。 2003$ 年的 3 月 5 月, 7 月～ 10 月，2004 年的 7 月 $~ 9$ 月，在紫茎泽兰的分布区 (23 个县)设置临时样地 171 块(其中云南 120 块，广 西 9 块, 贵州 12 块, 四川 27 块, 重庆 3 块)。

调查项目包括 样地的经纬度、海拔、坡向 (西坡 $45^{\circ} \sim 135^{\circ}$, 南坡 $135^{\circ} \sim 225^{\circ}$, 东坡 $225^{\circ} \sim 315^{\circ}$, 北坡 $315^{\circ} \sim 45^{\circ}$ ) 、坡度 $\left(7\right.$ 级: $0 \sim 2^{\circ}, 3^{\circ} \sim 5^{\circ}, 6^{\circ} \sim 15^{\circ}, 16^{\circ} \sim$ $30^{\circ}, 31^{\circ} \sim 45^{\circ}, 46^{\circ} \sim 60^{\circ}, 61^{\circ} \sim 75^{\circ}$ ) (孙鸿烈等, 1996 )、 风向坡(向风、背风、侧风) 紫茎泽兰的盖度和多度。

研究的因子较多，它们之间可能存在共线性，因 此对经纬度、海拔、坡向、坡度、风向坡之间的相关性 进行了检验, 以确定是否需要进行主成分分析 (PCA)。通过方差分析和多重比较来研究 6 个因子 对紫茎泽兰盖度和多度的影响。插图在 EXCEL 中 完成, 统计过程使用 SPSS11.5 和 Origin5.0 完成, 差 异显著检验中 $p<0.05$ 。

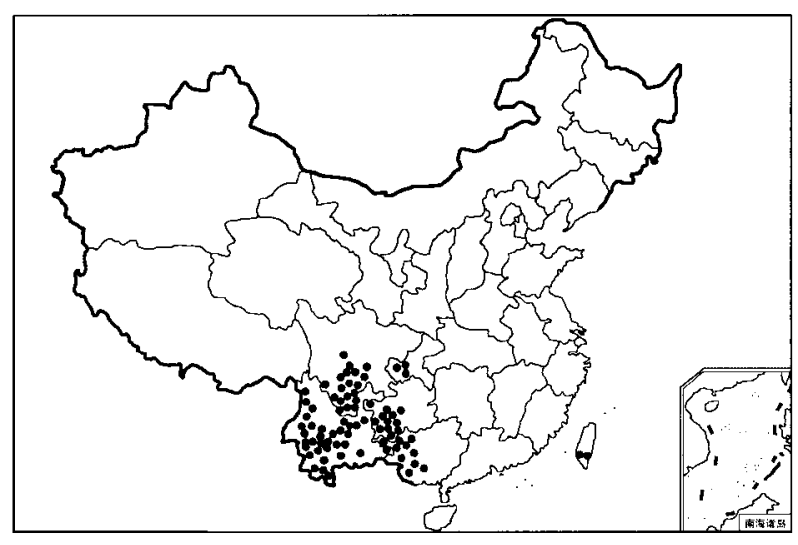

图 1 紫茎泽兰在中国的分布范围

Fig. 1 The range of Eupatorium adenophorum in China

\section{2 实验结果}

球形检验的假设被拒绝(表3)，表明6个因子 
表 1 紫茎泽兰分布区区划以及样地分布

Table 1 The range classification of Eupatorium adenophorum and the distribution of the plots

\section{生境类型(植被区) \\ Habitat type (Province)}

\section{样地所在位置}

Plot location
样方数量

Plot number
贵州山原 栲类、青冈林、石灰岩植被区 Guizhou mountainous plateau，Castanopsis , Cyclobalanopsis forest and limestone plant community

川滇黔山丘，栲类，木荷林区 Sichuan，Yunnan and Guizhou massif , Castanopsis， Schima forest

黔桂石灰岩丘陵山地,青冈、仪花林区 Guizhou and Guangxi limestone hill and mountain , Cyclobalanopsis and Lysidice rhodostegia forest

滇中高原盆谷, 滇青冈、栲类、云南松林区 Central Yunnan plateau, basin and valley, Cyclobalanopsis glaucoides, Castanopsis and Pinus yunnanensis forest

川、滇金沙江峡谷,云南松、干热河谷植被区 Sichuan and Yunnan Jinshajiang gorge, Pinus yunnanensis and dry hot river valley vegetation

滇西高山纵谷，具有铁杉、冷杉垂直分布林区 West Yunnan, alpine and valley, vertically distributed Tsuga and Abies forest

滇黔桂石灰岩峰林, 润楠、青冈、细叶云南松林区 Yunnan, Guizhou and Guangxi limestone hills, Machilus, Cyclobalanopsis, Pinus yunnanensis var. tenuifolia forest 滇中南中山峡谷 栲类、红木荷、思茅松林区 Central and south Yunnan , mountain and valley, Castanopsis , Schima wallichii and Pinus khasya forest

桂西南石灰岩丘陵山地, 季雨林区 Southwest Guangxi, limestone hill and mountain , seasonal rain forest

滇东南峡谷中山 , 半常绿季雨林、雨林区 Southeast Yunnan, valley and mountain , semi-evergreen seasonal rain forest and rain forest

西双版纳间山盆地，季节雨林、季雨林区 Xishuangbanna, basin with hills, season rain forest and seasonal rain forest

滇西南河谷山地, 半常绿季雨林区 Southwest Yunnan valley and mountain, semievergreen seasonal rain forest
关岭 Guanling

重庆 Chongqing

乐业、望谟 Leye, Wangmo

昆明 Kunming

盐源、西昌、冕宁、汉源、沪定 Yanyuan,

Xichang, Mianning, Hanyuan , Luding

贡山 Gongshan

元江、开远 Yuanjiang , Kaiyuan

临沧、沧源、西盟、龙陵、沪水 Lincang,

Cangyuan , Ximeng , Longling, Lushui

60

南宁、靖西 Nanning, Jingxi

6

河口 Hekou

预腊 Mengla

3

瑞丽 Ruili




表 26 个因子的相关系数矩阵

Table 2 Correlation matrix of the six factors

\begin{tabular}{|c|c|c|c|c|c|c|}
\hline & $\begin{array}{c}\text { 海拔 } \\
\text { Elevation }\end{array}$ & $\begin{array}{c}\text { 经度 } \\
\text { Longitude }\end{array}$ & $\begin{array}{c}\text { 纬度 } \\
\text { Latitude }\end{array}$ & $\begin{array}{l}\text { 坡向 } \\
\text { Aspect }\end{array}$ & $\begin{array}{l}\text { 坡度 } \\
\text { Slope }\end{array}$ & $\begin{array}{c}\text { 风向坡 } \\
\text { Wind slope }\end{array}$ \\
\hline 海拔 Elevation & 1.000 & & & & & \\
\hline 经度 Longitude & -0.332 & 1.000 & & & & \\
\hline 纬度 Latitude & -0.035 & 0.332 & 1.000 & & & \\
\hline 坡向 Aspect & 0.130 & 0.157 & -0.020 & 1.000 & & \\
\hline 坡度 Slope & 0.089 & 0.180 & 0.089 & 0.299 & 1.000 & \\
\hline 风向坡 Wind slope & 0.000 & 0.214 & 0.084 & 0.441 & -0.006 & 1.000 \\
\hline
\end{tabular}

表 36 个因子的 KMO 和 Bartlett's 检验

Table 3 KMO and Bartlett's test of the six factors

\begin{tabular}{clc}
\hline \multicolumn{2}{c}{ 抽样适宜性测度 (KMO 统计量) } \\
sampling adequare of & \\
\hline 球形检验 Bartlett's stest of sphericity & Approx. $\chi^{2}$ & 0.477 \\
& df & 109.039 \\
& Sig. & 0.000 \\
\hline
\end{tabular}

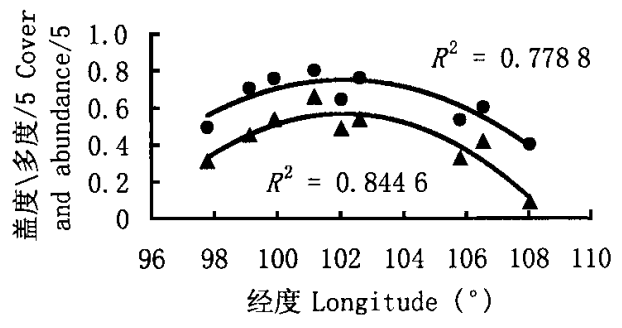

A盖度 Coverage - 多度 $/ 5$ Abundance $/ 5$

图 3 紫茎泽兰入侵与经度的关系

Fig.3 The relationship between invasion of Eupatorium adenophorum and longitude

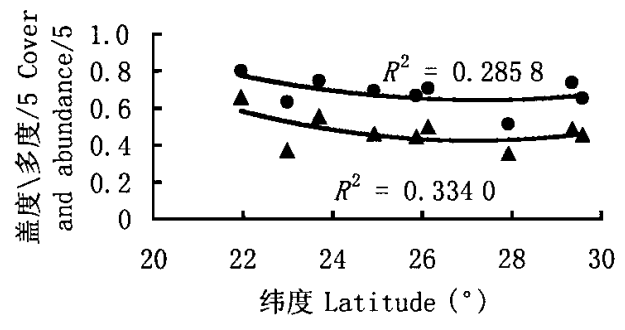

A 盖度 Coverage ・多度/5 Abundance/5

图 4 紫茎泽兰入侵与纬度之间的关系

Fig. 4 The relationship between invasion of Eupatorium adenophorum and latitude

并不显著 $(p>0.05$ ) (图 7)。

\section{5 风向坡对紫茎泽兰入侵的影响}

紫茎泽兰的瘦果很轻 $\left(4 \times 10^{-5} \mathrm{~g}\right)$, 借助风力入 侵新的领域(Auld \& Martin,1975) ,而果实成熟期间， 分布区内盛行西南季风(向业勋,1991)。因此，我们 对不同风向坡的入侵情况进行了统计分析。西南坡 $\left(90^{\circ} \sim 180^{\circ}\right)$ 为向风坡, 东北坡 $\left(270^{\circ} \sim 360^{\circ}\right)$ 为背风
坡, 东南坡 $\left(180^{\circ} \sim 270^{\circ}\right)$ 、西北坡 $\left(0 \sim 90^{\circ}\right)$ 和平地为 侧风坡。ANOVA 结果表明, 凤向坡对紫茎泽兰的盖 度影响不显著 $(p>0.05)$, 而对多度的影响显著 $(p$ $<0.05)$, 背风坡的多度显著大于侧风坡(图 8)。

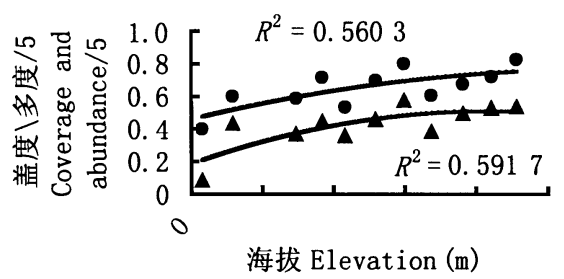

$\Delta$ 盖度Coverage • 多度/5 Abundance/5

图 5 紫茎泽兰与海拔之间的关系

Fig.5 The relationship between invasion of Eupatorium adenophorum and elevation

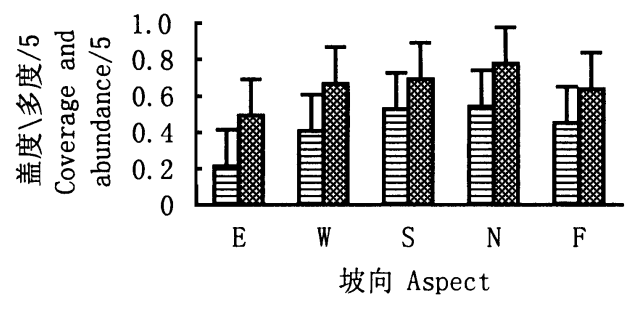

目盖度Coverage 因多度/5 Abundance/5

图 6 不同坡向紫茎泽兰的入侵情况

Fig.6 The invasion of Eupatorium adenophorum on different aspects

$\mathrm{E}$ : 东坡 East facing slopes $\mathrm{W}$ : 西坡 West facing slopes $\mathrm{S}$ : 南坡 South facing slopes $\mathrm{N}$ : 北坡 North facing slopes $\mathrm{F}$ : 平地 Flat

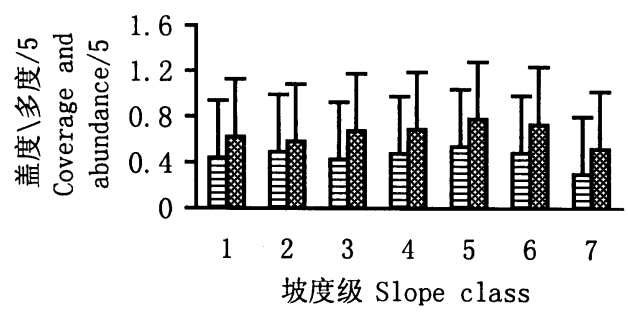

目盖度Coverage 多度/5 Abundance/5

图 7 不同坡度上紫茎泽兰的入侵情况

Fig.7 The invasion of Eupatorium adenophorum on different slopes 


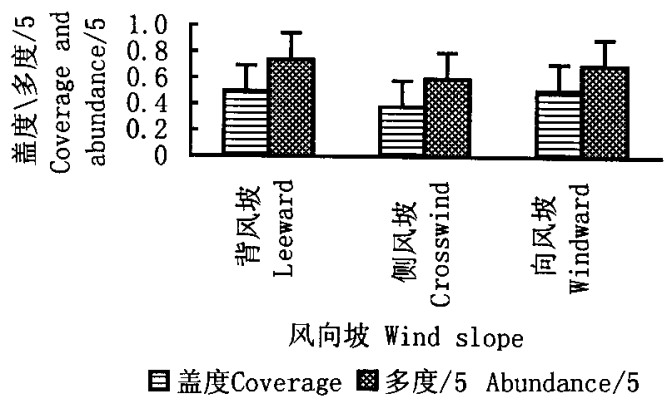

图 8 不同风向坡紫茎泽兰的入侵情况 Fig. 8 The invasion of Eupatorium adenophorum on different wind slopes

\section{3 讨 论}

\section{1 紫茎泽兰在中国的分布与扩散趋势}

目前, 紫茎泽兰在我国主要分布在云贵高原, 尤 其以云南高原最为集中。这与云南靠近有紫茎泽兰 分布的缅甸有关, 更重要的是因为云贵高原与紫茎 泽兰原产地的自然条件更为相似。

紫茎泽兰在原产地墨西哥主要分布在 Guanajuato, Guerrero, Hidalgo, Mexico, Michoacan, Morelos, Oaxaca，Puebla，Veracruz 等地，集中在该国中南部地 区(Papes \& Peteron, 2003)。墨西哥是一个高原山地 国家, 年均温 $17 \sim 27{ }^{\circ} \mathrm{C}$, 年均降水量 $750 \sim 2000$ $\mathrm{mm}$ 。另一个原产地哥斯达黎加年均温 $16 \sim 25{ }^{\circ} \mathrm{C}$, 年均降水量 $2540 \mathrm{~mm}$ (中国地图出版社,1987)。

云贵高原与墨西哥高原、哥斯达黎加高原同属 于低纬高原(云南气象局，2003），包括贵州全部，云 南大部，以及桂西北、川西南、川东南、鄂西南与湘西 武陵山地等广大地区 (赵济,2003)。因此, 我们推 断 紫茎泽兰在不断地向东向北推进，但最终分布格 局还将以云贵高原为主体，随着分布区扩大到云贵 高原之外，它的扩展速度、危害程度都将逐渐降低。 Papes 和 Peteron 2003 年使用 GARP 模型预测甘肃、 宁夏、陕西、山西、河南和湖北等地区最容易被紫茎 泽兰入侵, 东北的辽宁和黑龙江 东南的福建和浙江 也都是紫茎泽兰的潜在分布区。紫茎泽兰能够忍受 的极端最低温度为 $-11.5{ }^{\circ} \mathrm{C}$ (赵国晶等, 1989) ,而 宁夏、辽宁和黑龙江已经在 $-12{ }^{\circ} \mathrm{C}$ 等温线以北，所 以我们认为紫茎泽兰的分布区很难达到以上地区， 但不排除在某些局域气候的条件下，形成斑块的可 能。造成这种偏差的原因可能是 Papes 和 Peteron (2003) 使用的是 USGS 等机构网络上提供的分辨率 较低的地形和气象资料。因此, 要更准确地预测紫 茎泽兰未来的扩散趋势, 以及某个省或者某个地区
紫茎泽兰发生的可能性, 需要采用分辨率更高的当 地地形和气象资料。

3.2 经纬度、海拔、坡向、坡度和风向坡对紫茎泽兰 的影响

随着经度增加, 紫茎泽兰的盖度和多度, 呈现钟 型变化趋势, 最大值出现在 $102^{\circ} \mathrm{E}$ 左右, 处于西昌攀枝花-昆明-思茅一线，显示这几个地区紫茎泽兰 的危害最为严重, 这与云南、四川两省 2002 年的调 查报告结果一致 ${ }^{1)}$ 。这种变化趋势可能与我国西高 东低的地势有关。随着纬度增加, 紫茎泽兰的盖度 和多度呈现逐渐降低的趋势, 这与太阳辐射的变化 趋势一致, 说明热量减少是这种变化的主要驱动力, 但影响并不显著 $(p>0.05)$ 。另外, 紫茎泽兰入侵程 度随着经纬度的变化, 还与入侵时间长短有关。

野外调查发现，紫茎泽兰适宜生长在海拔2000 $\mathrm{m}$ 左右, 但随着纬度的增加, 太阳幅射逐渐减少, 紫 茎泽兰垂直分布的上下限都可能会逐渐降低 (张文 辉等 2002)。赵国晶等(1989)研究发现紫茎泽兰在 云南的垂直分布海拔范围在 165 2915 m , 亦有 600 $\sim 3000 \mathrm{~m}$ 的报道 (刘伦辉等, 1985) ,李振宇等 (2002) 则认为该种的垂直分布上限为 $2500 \mathrm{~m}$ 。刘 伦辉等 (1985) 在云南地区的研究表明: 紫茎泽兰多 在 $1000 \sim 2400 \mathrm{~m}$ 范围内形成密集的单优群落。紫 茎泽兰在年平均温度大于 $10{ }^{\circ} \mathrm{C}$ 绝对最低温度大于 - $11.5{ }^{\circ} \mathrm{C}$ 以上 绝对最高温度小于 $35{ }^{\circ} \mathrm{C}$, 最冷月平 均温度大于 $6{ }^{\circ} \mathrm{C}$ 的气候条件下适宜生长(赵国晶等, 1989)。Auld(1970)发现紫茎泽兰主要发生在没有霜 冻, 年平均降雨超过 $1524 \mathrm{~mm}$ 的地区。而随海拔变 化最为显著的因子是温度, 因此, 紫茎泽兰垂直分布 范围的主要限制因子可能是温度。

坡向对紫茎泽兰的入侵影响显著, 北坡和南坡 的盖度比东坡大北坡的多度比东坡大。比较而言， 东坡不易被入侵。坡向之间，太阳辐射差别最大，南 坡的太阳辐射最多，北坡最少，东西坡居中，各个坡 向的温度分布与太阳辐射类似。而土壤湿度的变化 与太阳辐射相反。坡向对空气湿度的影响与对土壤 湿度的影响类似。因此，南坡接受的太阳辐射较多， 温度较高, 湿度较低, 而北坡则相反。但北坡和南坡 紫茎泽兰的盖度和多度差异并不显著 $(p>0.05)$, 说 明温度与湿度不是造成坡向间紫茎泽兰入侵差异的 主导因素, 可能与紫茎泽兰生态幅较宽有关, 使之能 够在光照和水分条件完全不同的两个坡向入侵定 居。Auld(1970)的研究也表明紫茎泽兰对坡向没有 明显的倾向。 
坡度是影响土层厚度、土壤水分含量、有机质含 量的一个基本因素(刘福昌, 1996), 同时也影响太阳 辐射。但坡度对紫茎泽兰的盖度与多度影响并不显 著, 说明紫茎泽兰的分布与土壤结构和排水条件等 关系不显著。Auld(1969) 发现紫茎泽兰更多地分布 在 $20^{\circ}$ 或者大于 $20^{\circ}$ 的坡地上。这可能与评价紫茎泽 兰入侵的指标不同有关,Auld 统计的是紫茎泽兰出 现的频率, 而本研究中, 使用的是盖度和多度; 也可 能与紫茎泽兰在中国和澳大利亚分布区自然条件的 差异有关。

风向坡是坡向生态效应的一个方面。4 月中旬 到 5 月中旬为紫茎泽兰果实成熟期, 正直多风的旱 季末期(刘伦辉等, 1985) ,分布区内盛行西南风(向 业勋,1991)。结果显示:种子成熟期间的西南风对 紫茎泽兰的盖度影响不显著 $(p>0.05)$, 而对多度的 影响显著 $(p<0.05)$, 背风坡(东北坡)的多度显著大 于侧风坡(东南坡、西北坡和平地)。差异可能是由 两个坡向风速的不同造成的。在背风坡, 流线辐散， 风速迅速减小, 产生背风涡旋, 而侧风坡的风速要大 于前者(贺庆棠, 1986)。由于风速降低, 紫茎泽兰的 瘦果在背风坡更容易降落 种源比侧风坡丰富, 而且 东北坡的水分条件相对较好, 最终导致背风坡紫茎 泽兰的多度大于侧风坡。

综上所述地形因素主要通过影响太阳辐射、土 壤和繁殖体散布等对紫茎泽兰的盖度和多度产生作 用。作用机制包括以下 4 个方面 : 影响景观内各点 的局部温度 (包括地面和空气) 、湿度梯度和可利用 的营养物质, 改变景观内的能量、水、种子、有机和无 机物质的流动; 改变非地貌导致干扰的时间、频率和 位置, 这些干扰是由诸如火、风和放牧这类介质引起 的, 改变地貌过程的空间格局和频率, 而这些地貌过 程改变生物特征和过程(Swanson et al .,1988)。

\section{4 结 论}

紫茎泽兰目前主要分布在云南高原为主体的云 贵高原 将来的分布区将还是以云贵高原为主体;入 侵最严重的地区位于 $102^{\circ} \mathrm{E}$ 左右, 随着纬度的增加 入侵能力逐渐下降, 紫茎泽兰倾向于温凉气候, 适宜 生长在海拔 $2000 \mathrm{~m}$ 左右 ;东坡不易被入侵 坡度对 紫茎泽兰的入侵影响不显著,而风向坡的作用显著， 背风坡的入侵更加严重。

\section{参 考 文 献}

Auld, B. A. 1970. Eupatorium weed species in Australia. Pest Ar- ticles and News Summaries, 16: $82 \sim 86$.

Auld, B.A.\& P.M. Martin. 1975. The autecology of E. adenophorum Spreng. in Australia. Weed Research, 15:27 31 .

Auld, B.A. 1969. The distribution of E. adenophorum Spreng. on the Far North Coast of New South Wales. Journal and Proceedings, Royal Society of New South Wales, 102: 159 161 .

He, Q.T. (贺庆棠). 1986. Meteorology. Beijing: China Forestry Publishing House. 168. (in Chinese)

Li, B. (李博). 1993. General ecology. Huhhot: Inner Mongolia University Press. 51. (in Chinese)

Li, B. (李博). 1999. Ecology. Beijing: China Higher Education Press. 14. (in Chinese)

Li, Z.Y. (李振宇) \& Y. Xie (解炎). 2002. China exotic invasive species. Beijing: China Forestry Publishing House. 163. (in Chinese)

Liu, F.C. (刘福昌). 1996. On theoretical basis and methods for measuring the gradient of slopes and the application of the results. Journal of Guizhou Normal University (Natural Science Edition) (贵州师范大学学报 (自然科学版) ), 14: 7 13. (in Chinese with English abstract)

Liu, L.H. (刘伦辉), S.C. Xie (谢寿昌) \& J.H. Zhang (张 建华). 1985. Studies on the distribution, harmfulness and control of E. adenophorum Spreng. Acta Ecologica Sinica(生态学 报), 5:1 11. (in Chinese with English abstract)

Meng, X.X. (孟秀详), J.C. Feng (冯金朝), Y.J. Zhou (周 宜君), F.M. Wang (王富明), L. G. Qu (曲林古), C.J. Zhao (赵昌杰), Y.J. Zhu (朱印酒) \& H. Yang (杨红). 2003. Ecological factor analyzing of the invasion of crofton weed in south western Sichuan Province. Journal of the Central University for Nationalities (Natural Sciences Edition) (中央民族大学 学报 (自然科学版)), 12: $293 \sim 300$. (in Chinese with English abstract)

Papes, M. \& A.T. Peteron. 2003. Predicting the potential invasive distribution for E. adenophorum Spreng. in China. Journal of Wuhan Botanical Research (武汉植物学研究), 21: 137 142. (in Chinese with English abstract)

Parendes, L. A. \& J. A. Jones. 2000. Role of light availability and dispersal in exotic plant invasion along roads and streams in the H. J. Andrews Experimental Forest, Oregon. Conservation Biology, 14: $64 \sim 75$.

Qiang, S. (强胜). 1998. The history and status of the study on crofton weed ( $E$. adenophorum Spreng.), a worst worldwide weed. Journal of Wuhan Botanical Research (武汉植物学研 究), 16: $366 \sim 372$. (in Chinese with English abstract)

Shen, Z.H. (沈泽昊) \& X.S. Zhang (张新时). 2000. A Study on the classification of the plant functional types based on the topographical pattern of plant distribution. Acta Botanica Sinica(植 物学报), 42:1190 1196. (in Chinese with English abstract)

Sino Maps Press(中国地图出版社). 1987. World atlas. Beijing: Sino Maps Press. $71 \sim 72$. (in Chinese)

State Environmental Protection Administration of China(国家环境 保护总局) \& the Chinese Academy of Sciences (中国科学院). 2003. The list of exotic invasive species in China. http://www. zhb. gov.cn/download/1055369430488. doc. (in Chinese)

Sun, H.L. (孙鸿烈) \& G.S. Liu(刘光崧). 1996. Observation and analysis standard of Chinese Ecosystem Research Networkobservation and analysis on terrestrial biological community. Bei- 
jing: China Standard Press. 2. (in Chinese)

Swanson, F. J., T. K. Kratz, N. Caine \& R. G. Woodmansee. 1988. Landform effects on ecosystem patterns and processes: geomorphic features of the earth's surface regulate the distribution of organisms and processes. BioScience, 38: $92 \sim 98$.

Wang, H.J. (王洪昫)，P. He(何萍) \& J.L. Ma (马家林) . 1994. An investigation and research report on the dissemination of Ageratina adenophora on rangeland areas in Liangshan District of Sichuan Province. Grassland of China (中国草地), (1):62 64. (in Chinese with English abstract)

Wu，R. R. (吴仁润). 1984. The distribution, hazard and control of E. adenophorum and E. odoratum. Grassland of China(中国 草原), (2): 17. (in Chinese with English abstract)

Wu, Z. Y. (吴征镒). 1995. Vegetation of China. Beijing: Science Press. 758. (in Chinese)

Xiang, Y.X. (向业勋). 1991. The distribution, damage and control of E. adenophorum. Journal of Weed Science (杂草科学),
4:10 11. (in Chinese)

Yunnan Meteorological Bureau(云南省气象局). 2000. Meteorology study on low latitude plateau. http://www. ynmb. net/dw/ dwgy.htm. (in Chinese)

Zhang, W.H. (张文辉)\& Z.J. Lu (卢志军). 2002. A study on the biological and ecological property \& geographical distribution of Quercus variabilis population. Acta Botanica Boreali-Occidentalia Sinica (西北植物学报), 22: $1093 \sim 1101$. (in Chinese with English abstract)

Zhang, W. T. (张文䑣). 2002. The tutorial of SPSS11. Beijing: Beijing Hope Electronic Press. $190 \sim 201$. (in Chinese)

Zhao, G.J. (赵国晶)\& Y.P. Ma (马云萍). 1989. Investigation and study on the distribution and damage of E. adenophorum in Yunnan Province. Journal of Weed Science(杂草科学), 3: 37 $\sim 40$. (in Chinese)

Zhao, J. (赵济). 2003. Physiography of China. Beijing: China Higher Education Press. $225 \sim 226$. (in Chinese)

责任编委 : 党承林 责任编辑 :姜联合 